майбутнього вчителя музики втілюється в системі цілепокладання, мотивації, чуттєвообразній та інтелектуально-логічній сферах мислення (пізнання, переживання й оцінки), комплексу музично-виконавських знань, вмінь і навичок, особистісної музичної культури, та музично-виконавського досвіду. Внаслідок сприйняття, аналізу та оцінювання музичного втору народжується новий рівень музичного мислення, що стає суттєвим фактором духовного існування особистості.

Підсумовуючи вищесказане, можемо констатувати, що розвиток музичних здібностей $\epsilon$ важливим складнтком інструментально-виконавської підготовки вчителів музики. Це надасть змогу глибоко i всебічно ознайомитись 3 композиторською творчістю представників різних стильових напрямків, творчо переосмислювати авторських задум музичного твору, створювати художньопереконливі виконавські інтерпретації.

До напрямів подальших наукових досліджень можна віднести визначення принципів та обгрунтування педагогічних умов розвитку музичних здібностей, аналіз та створення різних методик удосконалення музичних здібностей.

1. Асафьев Б. Музыкальная форма как процесс / Б. В. Асафьев. Л. Музыка,1971. - 223 с. 2. Вицинский А. В. Психологический анализ процесса роботи пианиста -исполнителя над музыкальным произведением / А. В. Вицинский // Известия АПНРСФСР - Вып 25. - М., 1950. - С. 180-194. 3. Ковалів В. Методика музичного виховання на релятивній основі / В. Я. Ковалів. - К. : Музична Україна, 1973. - 150 с. 4. Метнер К. Н. Повседневная работа пианиста и композитора/ К. Н. Метнер. 5. Проблемы музыкального мышления : [под. ред. М. Арановського].М. : Музыка, 1974. -335 с. 6. Пчелкина Т. Диагностика и развитие музыкальных спрособностей / Т. П. Пчелкина. - М. : Чистые пруды, 2006. - 30 с. 7. Теплов Б. Проблемы индивидуальных различий / Б. Теплов. - M.,1961. - C.116-142. 8. Цыпин Г. Обучение игре на фортепиано / Г. М. Цыпин. - М. : Просвещение, 1984. $-173 \mathrm{c}$.

УдК: 37.01:796.011.3

Евген Павлюк

\title{
ПРОБЛЕМНЕ НАВЧАННЯ ЯК ОСНОВА ФАХОВОЇ ПІДГОТОВКИ МАЙБУТНІХ ТРЕНЕРІВ-ВИКЛАДАЧІВ
}

Павлюк Є. О. Проблемне навчання як основа фахової підготовки майбутніх тренерів-викладачів.

У статті висвітлено класифікацію теоретико-методичних основ фахової підготовки майбутніх тренерів-викладачів 3 використанням системи проблемних завдань. Конкретизовано загальний зміст теоретико-методичних основ фахової підготовки майбутніх тренерів-викладачів. Важливим пріоритетом фахової підготовки майбутніх тренерів-викладачів $є$ розвиток професійної компетентності, що особливо характерно для студентів старших курсів.

Ключові слова: майбутні тренери-викладачі, фахова підготовка, проблемні завдання, теоретико-методичні основи, класифікація.

Павлюк Е. А. Проблемное обучение как основа профессиональной подготовки будущих тренеров-преподавателей.

В статье представлена классификация теоретико-методических основ профессиональной подготовки будущих тренеров-преподавателей с использованием 
системы проблемных задач. Конкретизировано общее содержание теоретикометодических основ профессиональной подготовки будущих тренеровпреподавателей. Важным приоритетом профессиональной подготовки будущих тренеров-преподавателей является развитие профессиональной компетентности, что особенно характерно для студентов старших курсов.

Ключевые слова: будущие тренеры-преподаватели, профессиональная подготовка, проблемные задания, теоретико-методические основы, классификация.

Pavliuk Ye. O. Problem-Based Learning as the Basis for the Future CoachesInstructors' Professional Training.

The article deals with the classification of the theoretical and methodological foundations of the future coaches-instructors' professional training with the use of problem tasks. The general content of theoretical and methodological foundations of the future coaches-instructors' professional training is concretized. An important priority of the future coaches-instructors' professional training is the professional competence development, especially for senior students.

Key words: future coaches-instructors, professional training, problem tasks, theoretical and methodological foundations, classification.

Аналіз різноманітних технологій забезпечення фахової підготовки майбутніх тренерів-викладачів свідчить про те, що вони суттєво відрізняються від попередніх організаційно, а змістовно грунтуються на відомих, які добре зарекомендували себе в педагогічній практиці фахової підготовки майбутніх фахівців, серед них і проблемне, яке не втратило своєї актуальності, а й набуло більшого значення, зокрема у фаховій підготовці майбутніх тренерів-викладачів.

Науково-дослідною роботою, базовою для підготовки та подання статті $\epsilon$ «Психолого-педагогічна система становлення особистості фахівця» (2009-2014 pp.), шифр роботи Н2 - 2009, державний реєстраційний номер 09 U 0002.

Сучасна професійна освіта передбачає реформування й удосконалення системи підготовки фахівців галузі фізичної культури, спорту та здоров'я людини. Значна роль у цьому належить інтеграції структури і змісту навчального процесу до Європейської системи освіти у вищих навчальних закладах, сутність якої полягає у спрямованості на перспективу загальноєвропейської системи вищої освіти, що побудована на спільності фундаментальних принципів функціонування, яка визначає та систематизує основні напрями викладання дисциплін, що вимагає оптимізації блоку дисциплін професійної підготовки майбутніх тренерів-викладачів до сучасних умов 3 використанням системи проблемних завдань.

Основними поняттями теорії проблемного навчання є: проблемність, проблемна ситуація, проблема, проблемне завдання, проблемне навчання, проблемні запитання.

У процесі фахової підготовки майбутніх тренерів-викладачів до професійної діяльності ми використали типологію проблемних ситуацій, запропоновану В. Кудрявцевим [2]:

- проблемна ситуація створюється тоді, коли є невідповідність між наявними системами знань у майбутніх тренерів-викладачів і новими вимогами, що виникають у процесі розв'язання нових навчальних завдань фахової підготовки. Суперечність може виникати між засвоєними раніше знаннями і новими фактами, які виявляються під час розв'язання певних завдань фахової підготовки майбутніх тренеріввикладачів; між однаковими за характером знаннями більш низького і вищого рівнів; між науковими і донауковими, життєвими та практичними знаннями; 
- можливість створення проблемних ситуацій у процесі фахової підготовки майбутніх тренерів-викладачів забезпечується тим, що перед майбутніми фахівцями постає різноманітність вибору із системи наявних знань, застосування якої може забезпечити правильне розв'язання проблемного завдання. Сюди відносяться ситуації практичного та індивідуального характеру, ефективність розв'язання яких залежить від правильного і повного вибору даних та актуалізації необхідних знань;

- проблемні ситуації виникають перед майбутніми тренерами-викладачами тоді, коли має місце пошук шляхів використання знань на практиці, їх застосування в змінених (порівняно з фаховою підготовкою) умовах;

- проблемні ситуації постають у тому випадку, коли наявна суперечність виникає між теоретично можливим шляхом розв'язання завдання i практичною недоцільністю вибраного способу, а також між практично досягнутим результатом виконання завдання фахової підготовки i відсутністю його теоретичного обгрунтування.

Оскільки проблемне навчання інтегрує прийоми і методи активізації, ми його розглядаємо як один із способів активізації розумової діяльності майбутніх тренеріввикладачів у процесі фахової підготовки. Застосовуючи порівняння, аналіз, синтез, абстрагування та узагальнення, майбутні тренери-викладачі отримують нову інформацію, а потім використовують іiі для розв'язання інших завдань. Оволодіння прийомами розумової діяльності, вироблення навичок самостійно мислити, нагромадження досвіду творчої роботи призводить майбутніх тренерів-викладачів до якісного нового ставлення не тільки до фахової підготовки, а й до власного професійного становлення під час навчання у ВНЗ.

Г. Атанов, опираючись на науково-діалектичний підхід, стверджує: «якщо в процесі навчання під час вивчення навчальної дисципліни відсутні суперечності, то таке навчання абстрактне, воно є мертвим. Знання, набуті таким чином, теж мертві. Оживити процес навчання, наповнити його рухом можна лише шляхом оголення суперечностей» [1].

У процесі проблемного навчання у процесі фахової підготовки можна використати логічні суперечності. Найбільш суттєвими 3-поміж них $є$ суперечності суджень. Вони найчастіше виникають під час конструювання, планування технологічних процесів, коли стикаються судження «можливо-неможливо», «раціонально-нераціонально», «впливає на процес позитивно чи негативно» тощо. Проблемні ситуації такого типу відіграють важливу роль у формуванні активної розумової діяльності майбутніх фахівців. Насамперед вони сприяють розвитку аналітико-синтетичної діяльності майбутніх тренерів-викладачів, у результаті чого розв'язання фахових завдань стає більш доказовим, а отже і раціональним [3].

Дуже важливим $є$ те, що такий поділ суперечностей дає змогу класифікувати, визначати типи проблемних ситуацій. Оскільки поділ суперечностей $є$ умовним, то i типи проблемних ситуацій можна вважати умовними. Визначення типів проблемних ситуацій $є$ надзвичайно важливим для практики проблемного навчання [3].

У контексті нашого дослідження нерозвязаним питанням $\epsilon$ класифікація теоретико-методичних основ фахової підготовки майбутніх тренерів-викладачів. Пропонована нами класифікація відрізняється від попередніх робіт визначенням професійної компетентності майбутніх тренерів-викладачів у процесі фахової підготовки, уточненням розділів характеристики професійної діяльності майбутніх тренерів викладачів та перспективами розвитку спорту як майбутньої професійної діяльності.

Mema cmammi: згідно 3 науковими цілями обгрунтувати класифікацію змісту 
теоретико-методичних основ фахової підготовки майбутніх тренерів-викладачів 3 використанням системи проблемних завдань.

Система формування знань грунтується на логічно зв'язаних розділах загальної характеристики професійної діяльності майбутнього тренера-викладача та особливостях змісту виробничих функцій, обгрунтуванні типових завдань діяльності майбутніх тренерів-викладачів, визначенні професійних компетенцій майбутніх тренерів-викладачів, розвитку професійної компетентності майбутніх тренеріввикладачів у процесі фахової підготовки.

Варто зазначити, що тут важливу роль відіграє розкриття наукового змісту навчального матеріалу та його зв'язок із життям. Це $\epsilon$ підгрунтям для впровадження у навчальний процес технології проблемного навчання. Проблеми варто підбирати більш значущі, пов'язані із характеристикою професійної діяльності майбутнього тренера-викладача, особливостями змісту виробничих функцій, типових завдань діяльності майбутніх тренерів-викладачів, розвитку професійної компетентності майбутніх тренерів-викладачів у процесі фахової підготовки, перспективи розвитку спорту, як майбутньої професійної діяльності тощо (табл. 1).

Таблиця 1.

Класифікація змістової основи професійної підготовки майбутніх тренерів-викладачів

\begin{tabular}{|c|c|c|c|c|c|}
\hline \multirow{2}{*}{$\begin{array}{c}\text { Наукові } \\
\text { цілі }\end{array}$} & \multicolumn{5}{|c|}{ Параметри } \\
\hline & \multicolumn{2}{|c|}{ Опис дисичиплін } & \multicolumn{2}{|c|}{ Пояснення явищ } & \multirow{2}{*}{\begin{tabular}{l} 
Передбачення \\
\multicolumn{1}{c}{ прочесів } \\
Перспективи \\
розвитку \\
спорту, як \\
майбутньої \\
професійної \\
діяльності
\end{tabular}} \\
\hline 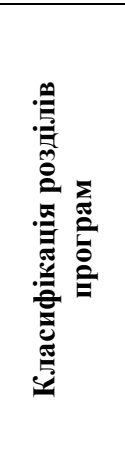 & $\begin{array}{l}\text { Загальна } \\
\text { характерис- } \\
\text { тика } \\
\text { професійної } \\
\text { діяльності } \\
\text { майбутнього } \\
\text { тренера- } \\
\text { викладача }\end{array}$ & $\begin{array}{l}\text { Особливос-ті } \\
\text { змісту } \\
\text { виробни-чих } \\
\text { функцій, } \\
\text { типові } \\
\text { завдання } \\
\text { діяльності } \\
\text { майбутніх } \\
\text { тренерів- } \\
\text { викладачів }\end{array}$ & $\begin{array}{l}\text { Професій- } \\
\text { ні } \\
\text { компетен- } \\
\text { ції } \\
\text { майбутніх } \\
\text { тренерів- } \\
\text { виклада- } \\
\text { чів }\end{array}$ & $\begin{array}{l}\text { Розвиток } \\
\text { професій- } \\
\text { ної } \\
\text { компетен- } \\
\text { тності } \\
\text { майбутніх } \\
\text { тренерів- } \\
\text { виклада- } \\
\text { чів у } \\
\text { процесі } \\
\text { фахової } \\
\text { підготов- } \\
\text { ки }\end{array}$ & \\
\hline 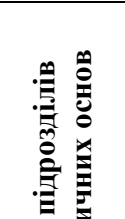 & $\begin{array}{l}\text { Специфіка } \\
\text { професійної } \\
\text { діяльності }\end{array}$ & $\begin{array}{l}\text { Особливос-ті } \\
\text { професій- ної } \\
\text { діяльності }\end{array}$ & $\begin{array}{l}\text { Основи } \\
\text { підго- } \\
\text { товки в } \\
\text { спортив- } \\
\text { них } \\
\text { школах }\end{array}$ & $\begin{array}{l}\text { Зміст } \\
\text { навчально- } \\
\text { трену- } \\
\text { вальних } \\
\text { занять }\end{array}$ & $\begin{array}{l}\text { Аналіз } \\
\text { проблем } \\
\text { розвитку } \\
\text { спорту }\end{array}$ \\
\hline 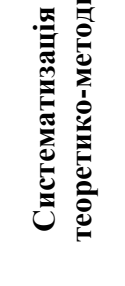 & $\begin{array}{l}\text { Матеріально- } \\
\text { технічне } \\
\text { забезпечен- } \\
\text { ня } \\
\text { професійної } \\
\text { діяльності }\end{array}$ & $\begin{array}{l}\text { Моделюва- } \\
\text { ння професій- } \\
\text { ної діяльності }\end{array}$ & $\begin{array}{l}\text { Методи } \\
\text { визна- } \\
\text { чення } \\
\text { резуль- } \\
\text { татів } \\
\text { професій- } \\
\text { ної } \\
\text { діяльності }\end{array}$ & $\begin{array}{l}\text { Мето-дика } \\
\text { прове- } \\
\text { дення } \\
\text { занять }\end{array}$ & $\begin{array}{l}\text { Науково- } \\
\text { методичне } \\
\text { забезпечення } \\
\text { діяльності }\end{array}$ \\
\hline
\end{tabular}




\begin{tabular}{|c|c|c|c|c|c|}
\hline \multirow{3}{*}{$\begin{array}{c}\text { Наукові } \\
\text { цілі }\end{array}$} & \multicolumn{5}{|c|}{ Параметри } \\
\hline & \multicolumn{2}{|c|}{ Опис дисциилін } & \multicolumn{2}{|c|}{ Пояснення явищ } & \multirow{2}{*}{\begin{tabular}{c} 
Передбачення \\
\multicolumn{1}{c}{ прочесів } \\
Визначення \\
перспектив \\
розвитку \\
спорту
\end{tabular}} \\
\hline & $\begin{array}{l}\text { Спортивний } \\
\text { інвентар, } \\
\text { сучасні } \\
\text { технічні } \\
\text { засоби }\end{array}$ & $\begin{array}{l}\text { Специфіка } \\
\text { виконання } \\
\text { професій- ної } \\
\text { діяльності }\end{array}$ & $\begin{array}{l}\text { Методи- } \\
\text { ка } \\
\text { навчання }\end{array}$ & $\begin{array}{l}\text { Теорія } \\
\text { трену- } \\
\text { вання у } \\
\text { виді } \\
\text { спорту }\end{array}$ & \\
\hline
\end{tabular}

На наше переконання, важливим пріоритетом фахової підготовки майбутніх тренерів-викладачів є розвиток професійної компетентності, що особливо характерно для студентів старших курсів. Зростання свідомого ставлення до навколишньої дійсності підсилюється ставленням майбутніх фахівців до навчання.

Більше уваги необхідно приділяти вмінню бачити та формулювати проблему. Уміння бачити проблему - це один із важливих показників професійного становлення майбутніх тренерів-викладачів.

Теоретико-методичні основи професійної підготовки відіграють важливу роль у процесі фахової підготовки майбутніх тренерів-викладачів. Якісну характеристикузміст знань 3 теоретико-методичних основ професійної підготовки складають сукупності елементів професійно важливих даних. Основою для успішного розвитку професійної компетентності майбутніх тренерів-викладачів $\epsilon$ певний обсяг попередніх специфічних знань, які набуті протягом багаторічного циклу навчально-тренувальних занять і змагань з обраного виду спорту, а також у процесі занять 3 психології спорту, вікової фізіології, загальної теорії олімпійського і професійного спорту, теорії і методики дитячого та юнацького спорту.

Через те, що знання $\epsilon$ перевіреним практикою результатом відображення дійсності в мисленні студента, навчальні заняття проходили у формі лекцій та практичних занять, а також циклу тренерсько-викладацької практики в дитячоюнацьких спортивних школах. Нами запропонований експериментальний чинник у вигляді допоміжного інтерактивного курсу «Теоретико-методичне забезпечення професійної підготовки до тренерсько-викладацької діяльності», ключовою формою якого є розвиток професійної компетентності з використанням системи проблемних завдань.

Згідно із структурною схемою професійної підготовки для формування знань на першому курсі включено теоретико-методичні основи обраного виду спорту та його техніко-тактичні особливості. У другому курсі: методику навчання обраного виду спорту. У третьому курсі: теорію та методику тренування в обраному виді спорту і на четвертому курсі - проблеми розвитку та шляхи їх розв'язання в обраному виді спорту.

На підставі проведеного констатувального етапу експерименту та згідно 3 класифікацією розроблено загальний зміст теоретико-методичних основ професійної підготовки майбутніх тренерів-викладачів відповідно до раціональної структури у вигляді інформаційної бази даних, яка складена на основі аналізу навчальних планів та кваліфікаційних характеристик підготовки бакалаврів 3 фізичної культури та спорту у ВН3.

Функція бази - науково-методичне забезпечення професійної підготовки і фахових дисциплін «Теорія і методика фізичного виховання», «Теорія і методика дитячого та юнацького спорту», «Зміст і види професійної діяльності фахівця 3 фізичної культури і спорту», «Спортивно-педагогічне вдосконалення», «Теорія і методика обраного виду спорту», «Олімпійський та професійний спорт», «Організація 
і методика спортивно-масової роботи», для студентів вищих навчальних закладів освіти.

Проведене дослідження і наш досвід упровадження проблемності у фахову підготовку майбутніх тренерів-викладачів переконують у тому, що ефективність проблемного навчання значно зростає за умови, якщо проблемні завдання будуть використовуватися в дидактично обгрунтованій системі. У процесі фахової підготовки майбутніх тренерів-викладачів ми використали систему проблемних завдань.

Перспективи подальших досліджень полягають у висвітленні методики реалізації системи професійного становлення майбутніх тренерів-викладачів у процесі фахової підготовки.

\section{Література}

1. Атанов Г. А. Деятельностный поход в обучении / Г. А. Атанов. - Донецк : ЕАИ-пресс, 2001. - 158 с. 2. Кудрявцев В. Т. Проблемное обучение: истоки, сущность, перспективы / $\quad$ В. Т. Кудрявцев. - $\quad$ М.: Знание, 1991. - 80 с. 3. Флоренский П. Наука - неотьемлемая часть культури / П. Флоренский, В. Зинченко // Вопросы философии. - 1990. - № 1. - С. 33-50.

\section{ІНШОМОВНА ПІДГОТОВКА СТУДЕНТІВ ЮРИДИЧНИХ СПЕЦІАЛЬНОСТЕЙ У КОНТЕКСТІ ЄВРОІНТЕГРАЦІЇ}

Побережна Н. О. Іншомовна підготовка студентів юридичних спеціальностей у контексті євроінтеграції.

У статті розглядаються питання іншомовної професійної підготовки студентів юридичних спеціальностей у контексті євроінтеграції. Обгрунтовано необхідність розроблення адаптивної моделі іншомовної підготовки для професійних цілей. Визначено та проаналізовано критерії оцінювання сформованості іншомовної професійної компетенції студентів юридичних спеціальностей.

Ключові слова: іншомовна професійна компетенція, стандартизований тест, методи контролю, адаптивна модель.

Побережная Н. А. Иноязычная подготовка студентов юридических специальностей в контексте евроинтеграции.

В статье рассматриваются вопросы иноязычной профессиональной подготовки студентов юридических специальностей в контексте евроинтеграции. Обоснована разработка адаптивной модели иноязычной подготовки для профессиональных целей. Определены и проанализированы критерии оценки сформированности иноязычной профессиональной компетенции студентов юридических специальностей.

Ключевые слова: иноязычная профессиональная компетенция, стандартизированный тест, методы контроля, адаптивная модель.

Poberezhna N. O. Foreign language training of students majoring in law in the context of European integration.

The article deals with the foreign language professional training of students majoring in law within the framework of European integration. The adaptive model of foreign language training for professional purposes is substantiated. Evaluation criteria for foreign language professional competence of students majoring in law are identified and analyzed.

Key words: foreign language professional competence, standard test, testing methods, 